\title{
Factors Influencing the Retention of Customers of Ghana Commercial Bank within the Agona Swedru Municipality
}

\author{
Rosemond Boohene ${ }^{1}$, Gloria K. Q. Agyapong ${ }^{1} \&$ Eric Gonu ${ }^{2}$ \\ ${ }^{1}$ Department of Management Studies, School of Business, University of Cape Coast, Ghana \\ ${ }^{2}$ Centre for Continuing Education, University of Cape Coast, Ghana \\ Correspondence: Rosemond Boohene, Department of Management Studies, School of Business, University of \\ Cape Coast, Cape Coast, Ghana. E-mail: rboohene@ucc.du.gh
}

Received: April 11, 2013

doi:10.5539/ijms.v5n4p82

\author{
Accepted: May 6, 2013 Online Published: May 28, 2013 \\ URL: http://dx.doi.org/10.5539/ijms.v5n4p82
}

\begin{abstract}
Customer retention is an important element of any banking strategy in today's increasingly competitive environment. This study examined the impact of retention factors that influence consumers' decisions to stay with Ghana Commercial Bank within the Agona Swedru Municipal area. The descriptive survey design was used for the research. Simple random sampling and self administered questionnaires were utilised to obtained data from 480 customers of the bank. Correlation and regression techniques were used to examine the relationships between customer satisfaction, service quality, customer trust, customer commitment, switching barrier factors and customer retention. The results revealed that on the whole, switching barrier emerged as the most significant factor influencing customer retention. This was followed by customer commitment and customer trust. The study recommends that management of the bank should pay attention to customer commitment by investing more into customer relationship marketing strategies that can increase customers' dependency and inhibit switching.
\end{abstract}

Keywords: relationship marketing, customer commitment, customer retention, switching cost, customer trust

\section{Background to the Study}

One of the ways by which every firm can survive is through effective relationship marketing strategies. The traditional marketing approach advocates the marketing mix principles and the quest for market share dominance through mass marketing techniques and a focus on new customer acquisition. This approach has guided managers for decades in planning and implementing their strategies. However, several authors have drawn attention to the inadequacies of the traditional marketing approach, which led to the birth of relationship marketing. According to Kotler (2001), relationship marketing has the aim of building long-term mutually satisfying relations with key parties; customers, suppliers, distributors, etc., in order to earn and retain their long-term preference and business.

Customer retention has been well emphasised in theories such as Richard's (1996) conversion model, Sharma and Patterson's (2000) relationship model, Ranaweera and Neely's (2003) holistic approach. All these theories seem to be making some statements, that customer retention brings benefits such as employee retention and satisfaction, better service, lower cost, lower price sensitivity, positive word-of-mouth, higher market share, higher efficiency and higher productivity.

Studies have shown that it is far more expensive to attract new customers than to retain existing ones. Fornell and Wernerfelt (1987) for example, emphasised that, marketing resources may be better spent on keeping existing customers than acquiring new ones. Also there have been several studies emphasising the significance of customer retention in the banking industry (Dawkins \& Reichheld, 1990; Reichheld \& Kenny, 1990; Marple \& Zimmerman, 1999). In addition, Cohen, Gan and Choong (2006) posit that retained customers bring a lot of benefits to banks.

The banking industry has grown from few institutions primarily involved in deposit acceptance and trade finance into a complex multi-player markets where large number of banks are operating with various technology, products and services activities. This has created a competitive environment which is geared towards working more at increasing market share in terms of retaining customers. However, Ghana Commercial Bank (GCB) can 
only survive, compete effectively and protect its market share in the midst of the current competition in the banking industry, if it will take all necessary steps to invest and retain its customers.

Various studies have been carried out in the developed countries regarding customer retention. However, only few studies have been carried out regarding customer retention in the developing world, especially in the banking sector and in Ghana (Appiah-Adu, 1999). A key question is what drives customer retention in a highly competitive service industry, characterised by low switching costs in a competitive market like Ghana? This study is being carried out to examine the factors that impact consumers' decision to stay with their current banks in Ghana and whether significant relationships exist between customer satisfaction, service quality, customer trust, customer commitment and switching barrier factors and customer retention at GCB.

The rest of the paper is organised as follows. A review of related literature is discussed in the next section. This is followed by the methodology section, results and discussions, conclusions and recommendations respectively.

\section{Literature Review}

This section is organised along the following themes; theories on customer retention, the concept of customer retention, factors that influence customer retention and conceptual framework for the study.

\subsection{Theories on Customer Retention}

Previous research conducted on the factors influencing customer retention have focused on retention from the customers' point of view. This is mainly due to the fact that several researchers perceive customer retention as the propensity for customers to stay with their services providers, and is therefore viewed as a behavioural factor (Ranaweera \& Prabhu, 2003a). This section discusses the frameworks and models illustrating the factors influencing customer retention from the customers' point of view. Two main theories have been selected including Richards (1996) conversion model and Sharma and Patterson's (2000) relationship commitment model.

\subsubsection{Conversion Model}

Richards (1996) provided a conversion model based on the fact that it is not enough to satisfy a customer as satisfaction alone does not predict customer behaviour. Richards (1996) argues that satisfied customers will leave, dissatisfied customers will remain and therefore, rather than discussing customer satisfaction, firm should discuss customer commitment. Payne (2006) also agrees that customer satisfaction helps to make customers committed, however, the building of committed customers involves more than merely satisfying them.

In building his model, Richards (1996) identified three factors as drivers of commitment. These are level of involvement, attraction of alternatives and the extent of ambivalence (See Figure. 1). Firstly, the level of involvement in the brand and category is one of the factors identified to drive commitment. According to Richards, the more people are involved in a given choice, the more carefully they will choose and once they have made their choices they often stick to it. Hence, if the customer is dissatisfied but involved, his primary strategy will be to try and repair the relationship rather than seeking other alternatives. On the other hand, if the customers are both dissatisfied and uninvolved, they would not even care about fixing the relationship but simply switch providers.

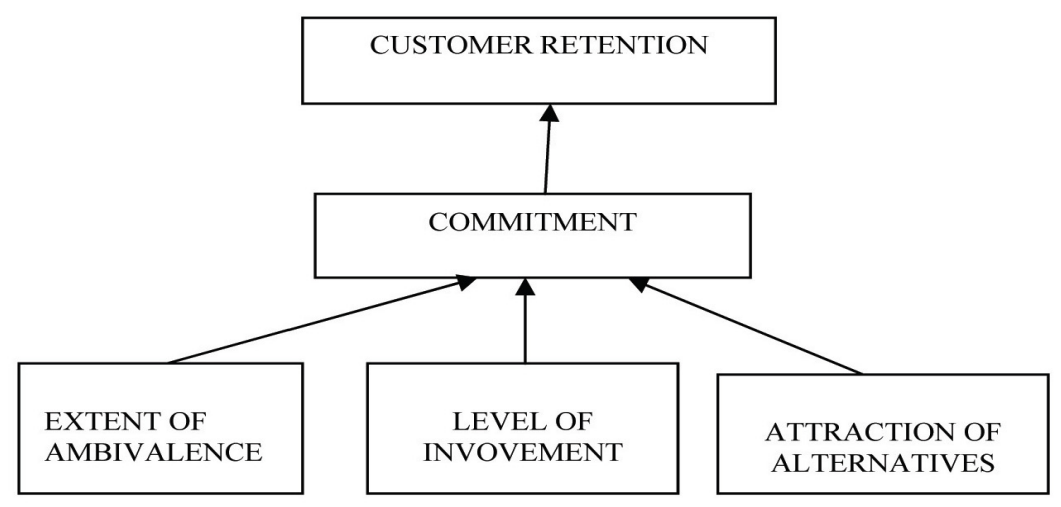

Figure 1. Richard's conversion model

Source: Richards, 1996. 


\subsubsection{Relationship Commitment Model}

Sharma and Patterson (2000) provide a model showing the determinants of relationship commitment. The model consists of three factors, namely communication effectiveness, technical quality and functional quality, all affected by trust in the relationship which in turns affect relationship commitment. According to Crosby, Evans, and Cowles (1990), trust implies reliance on or confidence in, the process or person. Hence, the greater the level of trust, the stronger the relationship commitment (see Figure 2). Sharma and Patterson (2000) also defined trust as the belief that the services provider can be relied on to behave in such a way that the long- term interests of the buyer will be served.

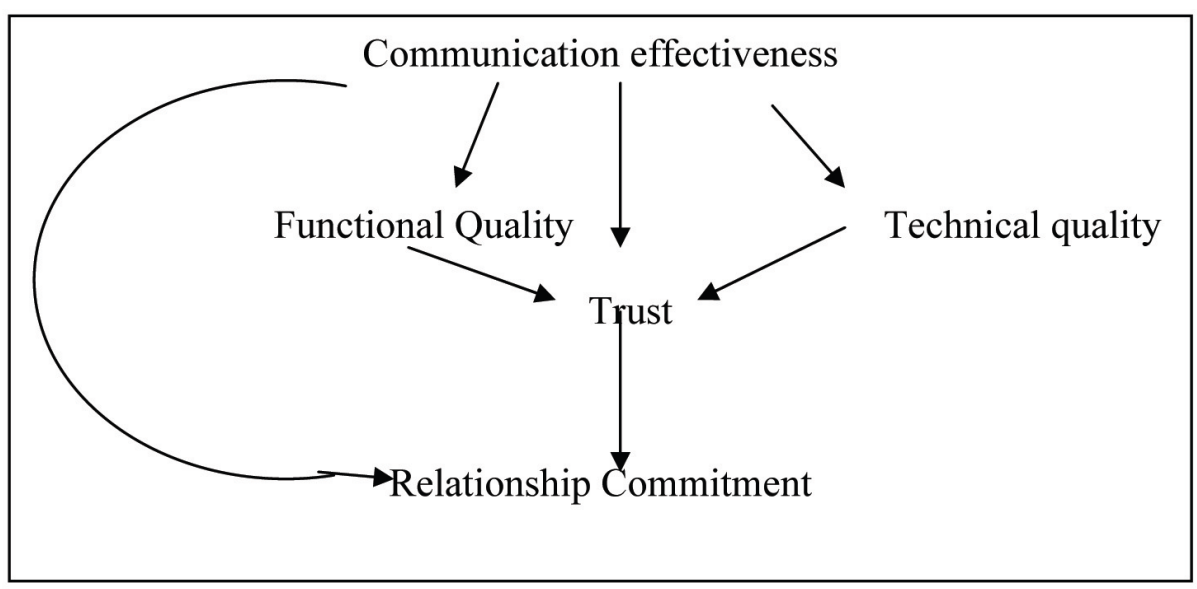

Figure 2. Conceptual model of the determinants of relationship commitment

Source: Sharma and Patterson, 2000.

Morgan and Hunt (1994) also argue that trust has a positive relation with the extent through which the firms share similar values. This was supported by Ganesan's (1994) studies which showed that a trust booster for firms was customers' satisfaction with past exchanges with the firms. According to Sharma and Patterson (2000), service quality is divided into two main components, namely technical quality and functional quality. Technical quality is related to the actual outcomes or the core service as perceived by the client. Jansson and Letmark (2005) posit that the competency of the professionals in achieving the best return on investment for their client at acceptable levels of risks is viewed and technical quality is relevant to the promised service. Sharma and Patterson (2000) further argued that, functional quality is concerned with 'what' is delivered and 'how' the service is delivered. It is concerned with the interaction between the service provider and service receiver, and is assessed in a highly subjective manner. According to them, trust had a great impact on how quality is delivered, both in terms of functional and technical quality. The greater the quality perceived, the stronger is the relationship commitment

\subsection{The Concept of Customer Retention}

Customer retention as a concept has its root from the planned behaviour theory and is something that consumers may exhibit to brands, services and products or activities. Customer retention has been conceptualised as a dimension of a customer loyalty construct (Zeithaml, Berry \& Parasuraman, 1996). The terms "customer retention" and "customer loyalty" are often used interchangeably in literature. However, customer retention and loyalty are not surrogates of each other because the two terms can refer to different things. Hennig-Thurau and Klee (1997) also suggested that the conceptualisation of customer retention needs further clarification. Zineldin (2000) views retention as a commitment to continue to do business or exchange with a particular company on an ongoing basis. A more comprehensive definition of retention is the customer's liking, identification, commitment, trust, willingness to recommend and repurchase intentions, with the first four being emotional-cognitive retention constructs and the last two being behavioural intentions (Strauss \& Friege, 2001). Customer retention is concerned with repeated patronage, which is closely related to repeat-purchasing behaviour and brand loyalty (Buttle, 2004).

Commitment is regarded as the central outcome variable in business relationships, which ensures the strength, stability, durability, and even profitability of a relationship (Morgan \& Hunt, 1994). In addition, customer 
retention implies a long-term commitment on the part of the customer and the firm to maintain the relationship. The development of the mutual commitment is the same process as creating long term buyer-seller relationships (Wilson, Soni \& O'Keeffe, 1995). According to Aspinall, Nancarrow, and Stone, 2001, even though the meaning and measurement of customer retention varies across industries, there seem to be a general consensus that a firm that focuses on customer retention by using the appropriate strategies can enjoy some economic benefits. (Buttle, 2004).

The benefits of retaining customers to the organisation are higher margins and faster growth, derived from the notion that the longer a customer stays with an organisation, generally the higher the profit (Reichheld \& Kenny, 1990). According to Bowen and Lawler (1995), if staff are given more power, greater access to information and adequate knowledge, they are in a better position to recover situations or delight customers. In addition, information systems also provide essential support for customer retention by keeping accurate details on purchase records, for assessing the value of customers to the organisation and in picking up likely defectors (Lewington, de Chernatony \& Brown, 1996). The significance of retaining customers is not new to marketing, as Kotler (2003) believed that marketing is as much concerned with retaining as well as acquiring customers. From review of literature, the following factors (customer satisfaction, customer commitment, customer trust) were found to influence customer retention. The next session discusses these concepts and their relationship with customer retention.

\subsubsection{Customer Satisfaction and Customer Retention}

Customer satisfaction has long been recognised in marketing theory and practice as both a core concept and the main goal of business activities (Anderson, Fornell \& Lehmann, 1994). Marketers take customer satisfaction as a significant determinant of positive word-of-mouth, consumer loyalty and repeat purchase (Kotler, Armstrong \& Cunningham, 2002). Oliver and Svan (1989) were of the view that satisfaction is broadly dedicated to be part of the confirmation or disconfirmation paradigm. Consumer satisfaction is acknowledged as a consumer's subjective evaluation of the outcomes and experiences associated with consuming or using the product or service (Oliver \& Svan, 1989). Additionally, Oliver (1997) defined satisfaction as a post-choice evaluative judgment in reference to a specific and purposeful decision it is also described as 'pleasurable fulfilment'. Kotler, Armstrong, and Cunningham (2002) also hold the view that satisfaction is also important to consumers because it represents a positive outcome for the money spent to fulfil their needs.

Customer satisfaction has a significant impact on repurchase intentions in a range of services (Patterson, Johnson \& Spreng, 1998). In addition, Kotler, Armstrong and Cunningham (2002) posit that satisfying customers' needs and wants ensures repeat purchase. Kotler (2003) also noted that, customer satisfaction is regarded as the key to customer retention and has been taken as a fundamental determinant of long-term customer behaviour and customer retention. According to Feinberg, Widdows, Hirsch-Wyncott and Trappey (1990), the probability of repurchase is not isomorphic with either positive or negative consumption experience. In the view of Oliva, Oliver and Lan (1995), there is a nonlinear and a symmetrical relationship between customer satisfaction repurchase intention, which presupposes that there is no direct relationship between customer satisfaction and repurchase intentions. A review of the marketing literature suggests that some controversies surrounding the relationship between customers' overall satisfaction and their repurchase intentions (Mitall, Rose \& Baldasare, 1998). Whereas some agree that there is no direct relationship between the two variables, others are of a contrary view. For example, Kotler et al. (2002) posit that there is a linear and symmetrical relationship between customer satisfaction and repurchase intentions. This means that customer satisfaction has a direct impact on repurchase intentions. From the discussions, even though there seem to be no consensus on the relationship between customer satisfaction and customer retention, some researchers still agree that there is some relationship between the two concepts. This research therefore proposes a significant positive relationship between customer satisfaction and customer retention.

\section{$\mathrm{H}_{1}$ : There is a significant positive relationship between customer satisfaction and customer retention.}

\subsubsection{Customer Commitment and Customer Retention}

Customer commitment has in many cases been identified as a crucial variable in the literature of relationship marketing (Sheaves \& Barnes, 1996). Additionally, Vavra (1995) also defined it as a management concept that describes a marketer's view of how to keep customers for life. The enthusiastic stream, for instance, supports the use of relational marketing strategy for all firms regardless of products or services.

The opposing stream protests that relational strategies are unsuitable and costly in an industry such as consumer retailing. The middle ground bears the view that different relationship proneness exists among different groups of customers in different industries (Christy, Oliver \& Penn, 1996). Peppers and Rogers (1997) view the work of 
relationship marketing in the consumer market in three very different ways. According to Wetzels, de Ruyter and Lemmink (2000), commitment is the core concept in the relationship-marketing paradigm and it is an enduring attachment to a seller. Meyer and Allen (1997) posit that the interpretation of commitment is not unanimous when referring to its attitudinal and behavioural nature. This view stands in contrast to viewing it as a multidimensional construct, though mostly applied to a business to business setting (Wetzels, et al 2000). Therefore, it can be interpreted that the unidimensional view is referring to a customer to business context. In addition, commitment has been taken as unidimensional (Gwinner \& Gremeler, 2002).

Despite the different views on commitment in the literature, most views support three dimensions of commitment, regardless of the subject being studied (Meyer \& Herscovitch, 2001). The three dimensions of commitment reflect different underlying psychological states, namely, affective commitment, continuance commitment and normative commitment. Affective commitment refers to the desire and willingness to stay with an organization. Fullerton (2005) also found it to be positively related to repurchase intentions. Continuance commitment is bound by the tangible and intangible costs to stay with the organization.

Fishbein and Ajzen (1980) posit that a person's intention is determined by personal nature and the social influence. The personal factor is the individual's positive or negative evaluation of performing the behaviour. This factor is known as attitude toward the behaviour, and it refers simply to the person's internal judgment. This judgment may be based on past experience, belief, educational background, understanding and character. These personal beliefs and subjective norms make up a person's intention and subsequent behavioural action. The theory of reasoned action model posits that commitment, an attitude toward a retailer, is a direct antecedent to loyalty (Sheaves \& Barnes, 1996). Once loyalty is solidified, consumers will resist persuasion to switch to or ignore information about goods or services from alternate, more inexpensive sources (Oliver, 1997). Fullerton (2005) posits that commitment is positively related to repurchase intentions. Therefore, from the discussions, it can be concluded that, commitment has a strong influence on customer retention.

\section{$\mathrm{H}_{2}$ : There is significant positive relationship between customer commitment and customer retention.}

\subsubsection{Customer Trust and Customer Retention}

Research into customer trust originated with the analysis of personal relationships. For instance, in the area of social psychology, trust can be regarded as an inherent characteristic of any valuable social interaction (Rempel, Homes, \& Zanna, 1985). In addition, the concept of trust, inspired by sociology (Lewis \& Weigert, 1985), economics (Dasgupta, 1988) and management (Ganesan, 1994), came into marketing literature following the relational orientation arising in marketing activities (Kotler, 2003).

In the financial services market, according to Bayne (1999), trust, together with honesty, fairness or excellence, has been taken as one of the basic consumer needs. Since customers might need reassurance to release their personal details and preferences, banks have to prove that they deserve to be trusted. The development and upkeep of trust in an online environment is critically important, especially in such a highly unpredictable market with reduced product differentiation as banking (Urban, Sultan \& Qualls, 2000). In addition, the absence of face-to-face contact creates a feeling of uncertainty and risk for customers (Delgado-Ballester, 2004).

According to Wirtz and Lihotzky (2003), building customer trust and convenience is the most appropriate strategy for commerce-based businesses. Customer trust significantly contributes to sales growth through customer acquisition and retention (Intermarket Group, 2004). Issues about privacy and security are major concerns for online shoppers, particularly unknown ones (Esch, Langner, Schmitt \& Geus, 2006). It is therefore hypothesised that

\section{$\mathrm{H}_{3}$ : There is significant positive relationship between customer trust and customer retention.}

\subsubsection{Service Quality and Customer Retention}

With the role of the customer changing gradually (Prahalad \& Ramaswamy, 2000), customers' perceived service quality has been given more and more attention for its specific contribution to the competitiveness of business and there have been a variety of studies on different issues concerning service quality over the last several years. These researchers believed that measuring service quality as disconfirmation is valid and allows service providers to identify several gaps in the service provided. However, most of these studies have found a poor fit for the disconfirmation model (Venetis \& Ghauri, 2004).

A review of literature reveals that the terms quality and satisfaction are quite often used interchangeably. While both concepts are related and appear to be merging, there are still gaps in understanding the two constructs, their relationship to each other and their antecedents and consequences (Gwynne, Ennew \& Devlin, 1999). Brady and Cronin (2001) posit that the effects of service quality on consumer decision-making appear to be largely indirect 
and mediated by value and satisfaction. According to Brady and Cronin (2001), service quality distinction is important to both managers and researchers alike, because service providers need to know whether their objective should be to have consumers who are satisfied with their performance or to deliver the maximum level of perceived service quality. In marketing and economics, quality often has been viewed as dependent on the level of product attributes. In service literature, quality is viewed as an overall assessment (Parasuraman, Zeithaml \& Berry, 1988, as cited in Boohene \& Agyapong, 2011).

In addition, the SERVQUAL model (Parasuraman et al., 1988), suggests that the difference between customer expectations about the performance of a general class of service providers and their assessment of the actual performance of a specific firm in that class results in perception of quality. This is also known as gap analysis. Also, the SERVQUAL model has been mostly applied as a model to analyse service quality and consumer expectation. Therefore, from the discussions, service quality has strong relationship with customer retention.

\section{$\mathrm{H}_{4}$ : There is significant positive relationship between service quality and customer retention.}

\subsubsection{Switching Barrier and Customer Retention}

According to Keaveney (1995), service switching may be due to critical incidents, such as attraction by competitors, inappropriate employee responses to service failures, pricing problems, core service failures, service encounter failures, lack of convenience, ethical problems or changes in the consumer's or service provider's situation (involuntary switching). In consumer goods settings, consumer loyalty has often been measured as a consumer's switching resistance when faced with competitors' counter persuasion; promotions, price decreases and/or stock shortage problems (Oliver, 1997). Furthermore, customer retention has become a top priority in service industries, since it has been proven to strongly affect profitability (Verhoef, 2003). However, preventing current customers from switching to other service providers is a very difficult task. During their lifetime, customers have many opportunities to switch service providers (competitor offers, sales promotions, etc.), and many events if the established relationship are likely to cause service relationship deterioration and dissolution (Gustafsson, Johnson \& Roos, 2005).

The other use of the term inertia in the literature is that the customer is lazy, inactive or passive (Zeelenberg \& Pieters, 2004). The literature on inertia offers two meanings. One perspective is that the customer is not able to change providers because the customer thinks that the alternatives are unattractive, there are highly perceived switching costs, or that there are other barriers to switching (White \& Yanamandram, 2007). Colgate and Lang (2001) posit that inertia is perceived as customers not switching because it is too much bother in terms of time and effort. This study therefore proposes a positive relationship between switching barrier and customer retention.

\section{$\mathrm{H}_{5}$ : There is a significant positive relationship switching barriers and customer retention.}

$\mathrm{H}_{6}$ : There is a statistically significant positive relationship between customer retention and other variables such as service quality, customer trust, switching barrier, customer satisfaction and customer commitment.

\section{Methodology}

\subsection{Study Design}

Cooper and Schindler (2006) refer to correlational design as a method of which attempts to determine whether and to what extent or degree a relationship exists between two or more quantifiable variables. Correlation research is sometimes referred to as descriptive research because it describes the relationship between variables but in a different way with the use of correlation coefficient. The purpose of correlation research is to explain important human behaviour and characteristics in quantitative terms and how they relate, and it also helps in prediction of events. Cooper and Schindler further stated that data collection tool for relationship study can be done by method including questionnaire.

The correlational study design was used for the study. The reason that necessitated the use of this design was the use of questionnaire which allowed the collection of large amount of data from a sizeable population. The study also involves the description of factors that contribute to customer retention and establish how the factors correlate with customer retention. Multiple regression was also adopted in analyzing data. The purpose of using regression analysis was to develop a group of independent variables such as service quality, customer trust, customer satisfaction, switching barrier and customer commitment that are useful in predicting the dependent variable which is customer retention. The regression analysis also helps to eliminate any of these variables that did not provide any additional prediction to customer retention in the equation (Pallant, 2005). The study used standard multiple regression so as to identify the contribution of the independent variable to the dependent 
variable. It was also used to identify the best predictor variable among the independent variables. According to Pallant (2005), the standard multiple regression also tells how much unique variance in the dependent variable each of the independent variables explained.

\subsection{Study Area}

The study was conducted in Agona-Swedru the capital town of the Agona Swedru Municipality. The location of the town makes it the commercial center and a nodal point from which roads radiate to the rich cocoa growing countryside of the region. There are five major commercial banks namely; HFC Bank, First National Bank, International Commercial Bank, Agricultural Development Bank and GCB. Besides, there are seven rural banks and several savings and loans companies operating within Agona Swedru. The municipality was chosen because it has in recent times witnessed the influx of investments, especially, banks and business growth. Moreover, the branch in Agona Swedru was chosen to be able to control for internal validity.

\subsection{Population and Sample}

The target population of the study comprised of 11,217 customers of Ghana Commercial Bank in Agona Swedru Municipal area. This was obtained from the database of Ghana Commercial Bank, Agona Swedru. The unit of analysis for this present study is the customers of Ghana Commercial Bank Limited, Agona Swedru Municipal Area (Ghana Commercial Bank, 2010). The reasons informing the researcher's selection of the population is that respondents possess the information required for the study and also respondents have certain attributes or characteristics that will make their responses meaningful. To ensure that an adequate number of responses were received, the sample size was determined using Hair, Bush and Ortinau's (2003) sample size determination formula. As with confidence interval, there are separate yet similar formulas for determining sample size based on a predicted population mean $(\mathrm{u})$ and a population proportion $(\mathrm{p})$. The appropriate standardized formula for calculating the necessary sample size would be:

$$
n=\left(Z^{2} B, C L\right)\left(\frac{\sigma^{2}}{\alpha^{2}}\right)
$$

Where;

$\mathrm{ZB}, \mathrm{CL}=$ The standardized $z$-value associated with the level of confidence

$\sigma=$ Estimate of the population standard deviation $(\sigma)$ based on some type of prior information.

$\alpha=$ Acceptable tolerance level of error (stated in percentage points)

Adopting this formula, the minimum required sample size was estimated to be 384 . However, in order to reduce the non response rate due to refusal to respond, ineligibility to respond and non-contact, this figure was increased to 480 to get a richer representation of the population. The procedure was adopted in order to make the sample more representative of the population. The study used simple random sampling method to select the respondents. Since the respondents had similar characteristics, the lottery method of simple random sampling was used to select 480 customers of the bank.

\subsection{Instrument}

The main instruments used for data collection were the questionnaire. According to Hair et al (2003), the questionnaire is the most common types of instruments used in survey research. Again, the questionnaire, on its part is effective when considering a large number of respondents and guarantees respondents' anonymity (Hair Black, Babin, Anderson and Tatham, 2006). Additionally, the questionnaire was used because it was considered to be more convenient as respondents could answer at their convenience. In this study, to make it attractive and interesting, the choice of close-ended and open-ended format was adopted because they were easier to be completed since they did not need any extensive writing. The items were also easier to be administered, coded and analysed.

\subsection{Measurement of Variables}

\subsubsection{Service Quality}

Service quality was measured by using the variables suggested in the SERVQUAL model (Ndubisi, Chan, \& Chukwunonso, 2004). In applying the SERVQUAL model, 21 statements were used to measure service quality across these elements, based on five- point Likert-scale type. The factors in the model were measured as follows: tangibles, reliability, responsiveness, assurance and empathy. 


\subsubsection{Customer Satisfaction}

Customer satisfaction (CS) was measured using a six-item, five-point Likert-type scale. The items were adopted and modified from the satisfaction measure developed by Rust and Zahorik (1994) that customer satisfaction reflects the degree to which a consumer believes that the possession or use of a service evokes positive feelings. Cohen, Gan and Choong, 2006) confirmed this view and drew upon the definition of satisfaction used consistently over time as an evaluation of an emotion. Customer satisfaction was thus measured by using customer complaint rate, negative affect/emotions, reluctance to switch, customer service, first choice and search motivation.

\subsubsection{Customer Commitment}

The customer's commitment to the bank relationship was measured using an eight-item, five-point Likert-type scale. The items were adopted and modified from the customer commitment measure developed by Sharma and Patterson, (2000), Chaudhuri and Holbrook (2001), Homburg and Giering (2001) and Jones, Mothersbaugh and Beatty (2002). These items tap the multiple facets of commitment incorporated in their definition, including the customer's loyalty, willingness to make short-term sacrifices, long-term orientation, and intention to invest in the relationship. Commitment was measured using switching cost, alternative attractiveness, prices, services offered and brand attitude.

\subsubsection{Customer Trust}

The customer's trust in the bank was measured by using a six- item, five-point Likert-type scale. The items were adopted and modified from customer trust measure developed by Gounaris (2005) and Ganesan (1994). These items were related to honesty, benevolence, integrity, relationship marketing strategy and competence of the supplier.

\subsubsection{Switching Barriers}

To measure switching barriers, a seven-item, five-point Likert-type scale in Clemes, Gan and Zhang (2010) was adopted, modified and used. Switching barrier was measured using prices, reputation, service quality, competitors' advertisement, involuntary factors, and bank's distance and switching cost.

\section{Results and Discussion}

This section presents the results of the regression analysis used to examine the relationships between the variables. The main purpose of the study was to gain insight into how customers of Ghana Commercial Bank within Agona Swedru Municipality perceive customer satisfaction, service quality, customer commitment, customer trust and switching barriers, and how these factors influence customer retention. Out of the 480 respondents, 430 of them returned their completed questionnaires yielding a sample return rate of $90 \%$. Pearson correlation matrix was used in addition to mean and standard deviation to test the first five hypotheses. Here, correlation was established between the factors and customer retention at 0.01 statistical significant levels. These factors were made up of many items. These items were pulled together to form each factor respectively. The following values of correlation interpretations suggested by Cohen (1988) were used as guidelines for the interpretation of the correlation results:

Correlation coefficient $(\mathrm{r})=.10$ to .29 or $\mathrm{r}=-.10$ to -.29

$$
\begin{array}{ll}
r=.30 \text { to } .49 \text { or } & r=-.30 \text { to }-.49 \\
r=.50 \text { to } 1.0 \text { or } & r=-.50 \text { to }-1.0
\end{array}
$$$$
\text { Very Weak }
$$

\section{Weak}

Strong

Table 1. Correlation coefficients between customers' perceptions on the factors and customer retention

\begin{tabular}{lllll}
\hline Factors & Mean & Std. Dev. & Customer retention & Sig. Values \\
\hline Service quality & 3.455 & .519 & $.456^{* *}$ & .000 \\
Customer trust & 3.141 & .532 & $.429^{* *}$ & .000 \\
Switching barriers & 3.408 & .502 & $.591^{* *}$ & .000 \\
Customer satisfaction & 3.819 & .574 & $.310^{* *}$ & .000 \\
Customer commitment & 3.349 & .565 & $.570^{* *}$ & .000 \\
\hline
\end{tabular}

**. Correlation is significant at the 0.01 level (2-tailed). 
The correlation matrix in Table 1indicates that a moderate and positive significant correlation was observed between service quality and customer retention $(\mathrm{r}=0.46$, $\mathrm{p}$-value $=0.000)$. The relationship indicates that moderate scores of service quality are associated with moderate scores of customer satisfaction. Hence, a moderate positive significant relationship was found between service quality and customer retention. This indicates that as service quality increases, customer retention increases and vice versa. This finding is consistent with the empirical studies of Reichheld (1996) and Ranaweera and Neely (2003). They both found that there was a positive association between perceived service quality and customer repurchasing or retention. This finding also corroborates Sharma and Patterson's (2000) assertion that the greater the quality is perceived, the stronger is the relationship commitment.

In addition, a moderate and positive significant relationships were observed between customer trust and customer retention $(\mathrm{r}=0.43, \mathrm{p}$-value $=0.000)$. The relationship indicates that medium scores of customer trust is associated with medium scores of customer retention. This indicates that as customer trust increases, customer retention increases and the opposite is true. According to Ganesan's (1994) study, a trust booster for firms was customers' satisfaction with past exchanges with the firms. The finding in this work also affirms the findings of Intermarket Group (2004) and Gounaris (2005), who demonstrated that customer trust significantly relate to sales growth through customer acquisition and retention. Thus, trust is a vital element in any type of relationship.

Furthermore, a statistically significant but weak positive relation was found between customer satisfaction and customer retention $(\mathrm{r}=0.31, \mathrm{p}$-value $=0.000)$. The relationship indicates that low scores of customer satisfaction are associated with low scores of customer retention. Hence, a positive but fairly significant relationship was found between customer satisfaction and customer retention. This implies that as customer satisfaction increases, customer retention also increases. However, if customer satisfaction decreases, customer retention also decreases This finding is congruent with Fornell (1992) finding that the more satisfied a firm's customers are, the more they remain loyal to the firm. Independent of customer satisfaction, however, other factors influence customer retention.

The correlation analysis also depicted a strong and positive significant relationships between switching barriers and customer retention $(\mathrm{r}=0.59, \mathrm{p}$-value $=0.000)$. This implies that as switching barrier increases, customer retention also increases and as switching barrier decreases customer retention decreases. The finding in this work however, affirms the findings of Lee et al. (2001) who tested and confirmed the positive effect of switching barriers on customer retention. Similarly, Ranaweera and Neely (2003) asserted that those who have positive perceptions of the service and also show a certain level of indifference, are the least likely to leave as their service expectations are fulfilled, and at the same time, they see no gains from switching.

The correlation matrix in Table 1 indicates that there was strong and positive significant relationships between customer commitment and customer retention $(\mathrm{r}=0.57$, $\mathrm{p}$-value $=0.000)$. The relationship indicates that higher scores of customer commitment are associated with higher scores of customer retention. This indicates that as customer commitment increases, customer retention also increases and when customer commitment decreases, customer retention also decreases. According to Patterson and Smith (2000), when customers are aware of, and perceive other suppliers as offering a differentiated service in terms of price, service and/or quality of technical outcomes, they tend to be less committed.

In order to find the strength of the relationship between the independent variables and the dependent variables and also test the sixth hypothesis, a hierarchical multiple regression was carried out using three models. The results are presented in table 2 .

Table 2. Hierarchical regression analysis

\begin{tabular}{lllllll}
\hline & \multicolumn{2}{l}{ Model I } & \multicolumn{2}{l}{ Model II } & Model III \\
& $\mathrm{B}$ & $\beta$ & $\mathrm{b}$ & $\beta$ & $\mathrm{B}$ & $\beta$ \\
\hline Constant & 1.017 & & 1.022 & & .861 & \\
Service Quality & .122 & $.119^{*}$ & .128 & $.125^{*}$ & .043 & .042 \\
Customer Trust & .180 & $.214^{* *}$ & .180 & $.214^{* *}$ & .161 & $.192^{* *}$ \\
Switching Barriers & .327 & $.371^{* *}$ & .328 & $.372^{* *}$ & .254 & $.288^{* *}$ \\
Customer Satisfaction & & & -.007 & -.009 & -.025 & -.032 \\
Customer Commitment & & & & & .249 & $.265^{* *}$ \\
\hline $\mathrm{R}$ & .566 & & .586 & & .796 & \\
R2 & .343 & & .345 & & .682 & \\
Adjusted R2 & .339 & & .350 & & .675 & \\
\hline
\end{tabular}


Dependent variable: Customer Retention; $b=$ unstandardised coefficients and $\beta=$ Standardised Coefficients.

$*$ and $* *$ indicate significance at $5 \%$ and $1 \%$ level respectively.

In the first model, the three variables were entered as independent variables (service quality, customer trust and switching barriers) and all the variables had a statistical significant association with customer retention. First, customer retention was used as the dependent variable. As Table 2 shows, the variables that predict customer retention in order of importance were switching barriers $(\beta=0.371, p$-value $=.026)$, customer trust $(\beta=0.214$, $\mathrm{p}$-value $=.000)$ and service quality $(\beta=0.119, \mathrm{p}$-value $=.000)$. It is however significant to observe that the proportional contribution of the three independent variables to the dependent variable (customer retention) is 0.343 with an adjusted $\mathrm{R}^{2}$ of 0.339 . As can be seen in Table 2, the result means that switching barriers, customer trust and service quality are able to predict or explain about $34 \%$ of the variance in customer retention. It therefore means that besides these variables identified, other variables not yet in the model have a chance of contributing or predicting about $66 \%$ to customer retention.

Again, in the second model in Table 2, customer satisfaction was entered in to the equation to serve as a mediating variable. The theory here is that the independent variables (service quality, customer trust and switching barriers) do not predict customer retention directly, and that they do so indirectly through customer satisfaction. When the variable customer satisfaction entered the equation, the beta coefficient of all the independent variables shrank slightly. The amounts of shrinkage of the factors are service quality $(86.6 \%)$, customer trust (93.9\%) and switching barrier (83.8\%). As showed in table 2, though customer satisfaction was not significant when it was entered into the second model, it did change the beta coefficients of other significant variables. What all the resultant shrinkages mean is that the independent variables predict customer retention more when customers are satisfied. In other words, the three independent variables in themselves do not explain customer retention more; they do so when customer satisfaction is present. The results also show that switching barriers, customer trust, service quality and customer satisfaction are able to predict or explain about $35 \%$ of the variance in customer retention. It therefore means that besides these variables identified, other variables not yet in the model have a chance of contributing or predicting about $65 \%$ to customer retention. This confirms the finding of Brady and Cronin (2001) in their submission that when there is customer satisfaction; then service quality, customer trust and switching barriers increase their potency as predictors of customer retention.

In the third model in Table 2, customer commitment was entered into the equation, and the result was that the coefficient of service quality lost its statistical significance $(\beta=.043$, $p$-value $=.509)$. This means that the explanatory power of the service quality factor is shared with the mediating variables. Therefore, service quality affects customer retention only when customers are committed. From the table, the coefficient for customer satisfaction was still not statistically significant $(\beta=-.025$, $\mathrm{p}$-value $=.535)$. The proportional contribution of the entered variables when customer commitment was added increased from 0.343 to 0.682 . Customer commitment variable was found to be statistically significant $(\beta=0.56, p$-value $=0.000)$ with an increase in adjusted $R^{2}$ over model 2 .

In comparing all $\mathrm{R}^{2}$ in the three models, it can be seen that when customer satisfaction was added to the independent variables in model two, the $\mathrm{R}^{2}$ figure increased from approximately 34 percent to approximately 35 percent indicating one percent contribution to $R^{2}$. Customer commitment came in to increase the $R^{2}$ to approximately 68 percent, representing 33 percent contribution to the $\mathrm{R}^{2}$. This means that customer commitment contributed more (33\%) to the $\mathrm{R}^{2}$ than the rest of the variables of the study.

\section{Conclusions and Implications}

The main objective was to examine the relationship between service quality, customer satisfaction, customer trust, customer commitment, switching barrier and customer retention. It can be concluded that, both switching barrier and customer commitment had strong and positive significant relationship with customer retention. Moderate and positive significant relationship was found between customer trust, service quality and customer retention. Customer satisfaction had weak positive relationship with customer retention. All the five variables in the conceptual framework of the research had significant positive relationships with customer retention. Therefore, the hypotheses that there are significant positive relationships between the selected factors and customer retention is true for all the variables.

The above conclusions indicate a need for certain strategies to be applied by organisations so that customer retention would continue to be high. It suggested that management of Ghana Commercial Bank, and other financial institutions should pay attention to customer commitment by investing more into customer relationship management that can increase customers' dependency and inhibit switching. There is also the need to focus on switching barrier factors such as transaction time, open more efficient branches closer to customers to make 
switching to other banks unattractive. It is also important to give much attention to customer retention by increasing customer satisfaction through the provision of accurate and timely information on products and services to its customers. The Ghana Commercial Bank should also ensure service quality through the continuous provision of fast, reliable and error-free transaction to customers. It is essential to maintain and build customer trust by providing best deals to customers that can be relied upon. Since the results of the study are based on consumers' perceptions only, future research should examine the relationship and congruence between consumers and service providers' perceptions on customer retention. This will help the industry to better understand whether both consumers and banks have the same opinion regarding retention issues. Also, while this study found that customer satisfaction had a weak but positive relationship with customer retention, future research may also attempt to explore some other constructs such as convenience issues that consumers and banks would value most.

\section{References}

Anderson, E. W., Fornell, C., \& Lehmann, D. R. (1994). Customer satisfaction, market share and profitability: Findings from Sweden. Journal of Marketing, 58, 53-66. http://dx.doi.org/10.2307/1252310

Appiah-Adu, K. (1999). Marketing effectiveness and customer retention in the service sector. The Service Industry Journal, 19(3), 26-41. http://dx.doi.org/10.1080/02642069900000028

Aspinall, E., Nancarrow, C., \& Stone, M. (2001). The meaning and measurement of customer Retention. Journal of Targeting, Measurement and Analysis for Marketing, 10(1), 79-87. http://dx.doi.org/10.1057/palgrave.jt.5740035

Bayne, T. (1999). Financial frogs and global Princes. The International Journal of SBank Marketing, 20(1), 18.

Boohene, R., \& Agyapong, G. K. Q. (2011). Analysis of the antecedents of customer loyalty of telecommunication industry in Ghana. International Business Research, 4(1), 229-240.

Bowen, D., \& Lawler, E. (1995). Empowering service employees. Sloan Management Review, 73-84.

Brady, M. K., \& Cronin, J. J. (2001). Some new thoughts on conceptualising perceived service quality: A hierarchical approach. Journal of Marketing, 21(4), 65-74.

Buttle, F. (2004). Customer relationship management: Concepts and tools. Elsevier, Oxford University Press.

Chaudhuri, A., \& Holbrook, M. B. (2001). The chain of effects from brand trust and brand affect to brand performance: The role of brand loyalty. Journal of Marketing, 65(2), 81-93. http://dx.doi.org/10.1509/jmkg.65.2.81.18255

Christy, R., Oliver, G., \& Penn, J. (1996). Relationship marketing in consumer Markets. Journal of Marketing Management, 12(6), 175-187. http://dx.doi.org/10.1080/0267257X.1996.9964407

Cohen, D., Gan, C., \& Choong, E. (2006). Customer satisfaction: A study of bank customer retention in New Zealand. Commerce Division, Discussion Paper No. 109.

Colgate, M., \& Lang, B. (2001). Switching barriers in consumer markets: An investigation of the financial services industry. Journal of Consumer Marketing, 18(4), 332-347. http://dx.doi.org/10.1108/07363760110393001

Cooper, D. R., \& Schindler, P. S. (2006). Business research methods (9th ed.) New York: McGraw Hill/Irwin.

Crosby, L. A., Evans, K. R., \& Cowles, D. (1990). Relationship quality in services selling: An interpersonal influence perspective. Journal of Marketing, 54(21), 68-81. http://dx.doi.org/10.2307/1251817

Dasgupta, P. (1988). Trust as a commodity: Making and breaking cooperative relations. New York: Basil Blackwell.

Dawkins, P. M., \& Reichheld, F. F. (1990). Customer retention as a competitive weapon. European Journal of Marketing, 14(6), 42-47.

Delgado-Ballester, E. (2004). Applicability of a brand trust scale across product categories: A multigroup

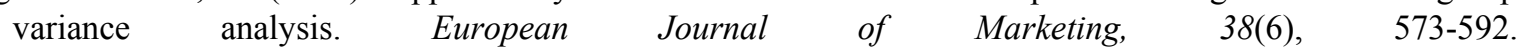
http://dx.doi.org/10.1108/03090560410529222

Esch, F. R., Langner, T., Schmitt, B. H., \& Geus, P. (2006). Are brands forever? How brand knowledge and relationships affect current and future purchases. The Journal of Product and Brand Management, 15(2), 98-105. http://dx.doi.org/10.1108/10610420610658938 
Feinberg, R. A., Widdows, R., Hirsch-Wyncott, M., \& Trappey, C. (1990). Myth and reality in customer service: Good and bad service sometimes leads to re-purchase. Journal of Consumer Satisfaction, Dissatisfaction, and Complaining Behaviour, 3(3), 112-114.

Fishbein, M., \& Ajzen, I. (1980). Belief, attitude, intention and behavior: An introduction to theory and research. Reading, MA: Addison-Wesley.

Fornell, C., \& Wernerfelt, B. (1987). Defensive marketing strategy by customer complaint management: A theoretical analysis. Journal of Marketing Research, 24(11), 337-346. http://dx.doi.org/10.2307/3151381

Fullerton, G. (2005). The impact of brand commitment on loyalty to retail service brands. Canadian Journal of Administrative Sciences, 22(2), 97-110. http://dx.doi.org/10.1111/j.1936-4490.2005.tb00712.x

Ganesan, S. (1994). Determinants of long-term orientation in buyer-seller Relationships. Journal of Marketing, 58(3), 1-19. http://dx.doi.org/10.2307/1252265

Ghana Commercial Bank. (2010). Annual reports. Retrieved July, 2011, from http://www.gcb.gh.com

Gounaris, S. P. (2005). Trust and commitment influence on customer retention. Journal of Business Research, 58(4), 126-140. http://dx.doi.org/10.1016/S0148-2963(03)00122-X

Gustafsson, A., Johnson, M. D., \& Roos, I. (2005). The effects of customer satisfaction, relationship commitment dimensions, and triggers on customer retention. Journal of Marketing, 69(4), 210-218. http://dx.doi.org/10.1509/jmkg.2005.69.4.210

Gwinner, K. P., \& Gremler, D. D. (2002). Relational benefits in services industries: The customer's perspective. Journal of the Academy of Marketing Science, 26(2), 101-14. http://dx.doi.org/10.1177/0092070398262002

Hair, J. F., Black, W. C., Babin, B. J., Anderson, R. E., \& Tatham, R. L. (2006). Multivariate data analysis (6th ed.). NJ: Prentice-Hall.

Hair, J. F., Bush, R. P., \& Ortinau, D. J. (2003). Marketing research within a changing information environment (2nd ed). New York: McGraw-Hill.

Hennig-Thurau, T., \& Klee, A. (1997). The impact of customer satisfaction and relationship quality on customer retention: A critical reassessment and model development. Psychology \& Marketing, 14(8), 737-764. http://dx.doi.org/10.1002/(SICI)1520-6793(199712)14:8<737::AID-MAR2>3.0.CO;2-F

Homburg, C., \& Giering, A. (2001). Personal characteristics as moderators of the relationship between customer satisfaction and loyalty - An empirical analysis. Psychology and Marketing, 18(1), 43-66. http://dx.doi.org/10.1002/1520-6793(200101)18:1<43::AID-MAR3>3.0.CO;2-I

Intermarket Group. (2004). Understanding customer trust in agent-mediated electronic commerce. Retrieved September 29, 2011, from http://www.springelink.com/index/T5184T33X046301X.pdf

Jansson, E., \& Letmark, M. (2005). Customer loyalty in internet banking context. Journal of Services Marketing, 13(5), 155-180.

Jones, M. A., Mothersbaugh, D. L., \& Beatty, S. E. (2002). Why customers stay: measuring the underlying dimensions of services switching costs and managing their differential strategic outcomes. Journal of Business Research, 55(9), 441-450. http://dx.doi.org/10.1016/S0148-2963(00)00168-5

Keaveney, S. M. (1995). Customer switching behavior in service industries: an exploratory study. Journal of Marketing, 59(2), 71-82. http://dx.doi.org/10.2307/1252074

Kotler, P. (2003). Marketing management (11th ed.). New Jersey, USA: Prentice-Hall.

Kotler, P. R. (2001). Marketing management, analysis, planning, implementation and control (8th ed.). Englewood Cliffs, NJ: Prentice-Hall.

Kotler, P., Armstrong, G., \& Cunningham, P. G. (2002). Principles of marketing. Englewood Cliffs, NJ: Prentice-Hall.

Lewington, J., Chernatony, L., \& Brown, A. (1996). Harnessing the power of database marketing. Journal of Marketing Management, 12, 329-346. http://dx.doi.org/10.1080/0267257X.1996.9964418

Lewis, D. J., \& Weigert, A. (1985). Trust as a social reality. Social Forces, 63, 967-985.

Marple, M., \& Zimmerman, M. (1999). A customer retention strategy. Mortgage Banking, 59(11), 45-50.

Meyer, J. P., \& Allen, N. J. (1997). Commitment in the workplace: Theory, research, and application. Thousand Oaks, CA: Sage Publication. 
Meyer, J. P., \& Herscovitch, L. (2001). Commitment in the workplace: Toward a general model. Human Resource Management Review, 11(3), 299-326. http://dx.doi.org/10.1016/S1053-4822(00)00053-X

Mitall, V., Rose, W. T., \& Baldasare, P. M. (1998). The asymmetric impact of negative and positive attribute-level performance on overall satisfaction and repurchase intentions. Journal of Marketing, 62(1), 33-47. http://dx.doi.org/10.2307/1251801

Morgan, R. M., \& Hunt, S. D. (1994). The commitment-trust theory of Relationship Marketing. Journal of Marketing, 58(3), 20-38. http://dx.doi.org/10.2307/1252308

Ndubisi, N. O., Chan, K. W., \& Chukwunonso, N. C. (2004). Evaluating relationship marketing strategies and customer loyalty. International Logistics Congress Proceeding, 11, Izmir.

Oliva, T. A., Oliver, R. L., \& Lan, C. M. (1995). A catastrophe model for developing service satisfaction strategies. Journal of Marketing, 56(3), 83-95. http://dx.doi.org/10.2307/1252298

Oliver, R. L. (1997). Satisfaction: A behavioral perspective on the consumer. New York: McGrawHill Companies. Inc.

Oliver, R. L., \& Svan, J. E. (1989). Equity and disconfirmation perceptions as influences on merchant and product satisfaction. Journal of Consumer Research, 14(3), 495-507.

Patterson, P. G., Johnson, L. W., \& Spreng, R. A. (1998). Modeling the determinants of customer satisfaction for business-to-business professional services. Journal of the Academy of Marketing Science, 25(1), 4-17.

Payne, A. (2006). Handbook of CRM: Achieving excellence in customer management. London: Butterworth-Heinemann.

Peppers, D., \& Rogers, M. (1997). Enterprise one-to-one, tools for competing in the interactive age. New York: McGraw/Irwin.

Prahalad, C. K., \& Ramaswamy, V. (2000). Co-opting customer competence. Harvard Business Review, 78(1), 79-87.

Ranaweera, C., \& Neely, A. (2003). Some moderating effects on the service quality-customer retention link. International Journal of Operations \& Production Management, 23(2), 230-248. http://dx.doi.org/10.1108/01443570310458474

Ranaweera, C., \& Prabhu, J. (2003). The influence of satisfaction, trust and switching barriers on customer retention in a continuous purchasing setting. International Journal of Service Industry Management, 14(4), 374-395. http://dx.doi.org/10.1108/09564230310489231

Reicheld, F., \& Kenny, D. (1990). The hidden advantages of customer retention. Journal of Retail Banking, XII(4), 19-23.

Rempel, J. K., Homes, J. G., \& Zanna, M. P. (1985). Trust in close relationships. Journal of Personality and Social Psychology, 49(1), 95-112. http://dx.doi.org/10.1037/0022-3514.49.1.95

Richards, T. (1996). Using the conversion model to optimize customer retention. Managing service quality, 6(4), 48-52. http://dx.doi.org/10.1108/09604529610120294

Rust, R. T., \& Zahorik, A. J. (1993). Customer satisfaction, customer retention, and market Share. Journal of Retailing, 69, 193-215. http://dx.doi.org/10.1016/0022-4359(93)90003-2

Sharma, N., \& Patterson, P. G. (2000). Switching costs, alternative attractiveness and experience as moderators of relationship commitment in professional, consumer services. International Journal of Service Industry Management, 11(5), 470-490. http://dx.doi.org/10.1108/09564230010360182

Sheaves, D. E., \& Barnes, J. G. (1996). The fundamental of relationships. Services Marketing and Management, 5(12), 320-368.

Strauss, B., \& Friege, C. (1999). Regaining service customers: costs and benefits of regain Management. Journal of Service Research, 1(4), 347-361. http://dx.doi.org/10.1177/109467059914006

Urban, G. L., Sultan, F., \& Qualls, W. J. (2000). Placing trust at the centre of your internet strategy. Sloan Management Review, 42(1), 39-48.

Vavra, T. G. (1995). After-marketing: How to keep customers for life through relationship marketing. Chicago: Irwin. 
Verhoef, P. C. (2003). Understanding the effect of customer relationship management efforts on customer retention and customer share development. Journal of Marketing Research, 67(4), 30-45. http://dx.doi.org/10.1509/jmkg.67.4.30.18685

Wetzels, M., de Ruyter, D., \& Lemmink, J. (2000). Antecedents and consequences of service quality in business-to-business services. Handbook of Services Marketing and Management. Thousand Oaks, CA: Sage.

White, L., \& Yanamandram, V. (2007). A model of customer retention of dissatisfied business services customers. Managing Service Quality, 17(3), 298-316. http://dx.doi.org/10.1108/09604520710744317

Wilson, D. T., \& Mummalaneni, V. (1990). Buyer-seller relationships as a bonding process. The Pennsylvania State University.

Wirtz, B., \& Lihotzky, N. (2003). Customer retention management in the B2C electronic business. Long Range Planning, 36(6), 517-532. http://dx.doi.org/10.1016/j.lrp.2003.08.010

Zeelenberg, M., \& Pieters, R. (2004). Beyond valence in customer dissatisfaction: a review and new findings on behavioural responses to regret and disappointment in failed services. Journal of Business Research, 57(4), 445-55. http://dx.doi.org/10.1016/S0148-2963(02)00278-3

Zeithaml, V. A., Berry, L. L., \& Parasuraman, A. (1996). The behavioural consequences of service quality. Journal of Marketing, 60(4), 31-46. http://dx.doi.org/10.2307/1251929

Zineldin, M. (2000). (TRM) Total relationship management, Student literature, Lund.

\section{Copyrights}

Copyright for this article is retained by the author(s), with first publication rights granted to the journal.

This is an open-access article distributed under the terms and conditions of the Creative Commons Attribution license (http://creativecommons.org/licenses/by/3.0/). 